whom pre-existing gout, cardiovascular and renal disease, and diabetes had been excluded, developed gout after four years. ${ }^{3}$ Recent data in healthy men from Boston show an annual incidence of gouty arthritis of $0.1 \%$ for urate concentrations below $420 \mu \mathrm{mol} / \mathrm{l}, 0.5 \%$ for those of $420-534 \mu \mathrm{mol} / 1$, and $4.9 \%$ for those of $540 \mu \mathrm{mol} / 1$ or more. ${ }^{4}$ The risk of developing gout thus seems to be low, and in any case gouty arthritis can be treated.

Acute uric acid nephropathy, in which massive deposits of uric acid crystals form within the renal tubule and pelvis, follows excessive nucleoprotein degradation, which occurs most commonly after chemotherapy for malignant disease. It is easily prevented by allopurinol. Estimations of the frequency of stone formation among patients with gout range from $4 \%{ }^{5}$ to $73 \%,{ }^{6}$ and stones may be associated with hyperuricaemia without gout. Interstitial deposition of sodium urate may impair renal function, but abnormalities of tubular or glomerular function may themselves lead to hyperuricaemia - and working out the sequence of events in an individual patient is often difficult. The risks do not, however, seem to be great. A recent American survey of many people with hyperuricaemia and normouricaemic controls followed over years showed that azotaemia attributable to hyperuricaemia is generally mild and no more common than azotaemia in normouricaemic people. ${ }^{7}$ The risk was thought to be of no clinical importance (at least until serum concentrations of urate were very high), and the risks of urolithiasis also seemed small. Another investigation in which glomerular and tubular function was measured in many patients also showed that hyperuricaemia (or uncomplicated gout alone) does not in itself cause renal insufficiency. ${ }^{8}$ When renal insufficiency is seen in patients with gout it tends to be related to hypertension, ischaemic heart disease, or pre-existent renal insufficiency. Similarly, the Boston study found no evidence of renal deterioration attributable to hyperuricaemia. ${ }^{4}$

The results of numerous studies have yielded conflicting results on the relation of asymptomatic hyperuricaemia to cardiovascular disease. Although hyperuricaemia may be related to heart disease if the patient is obese, hypertensive, and taking medication, hyperuricaemia has not been shown to be an independent risk factor. ${ }^{9}$ The evidence thus invites a conservative approach to the man or woman with asymptomatic hyperuricaemia. A full clinical assessment is necessary, as for a patient with gout, with particular reference to dietary and drug (diuretic) history and cardiac and renal function. Overproduction of uric acid (indicating the possibility of a specific purine enzyme abnormality with its genetic implications and the increased risk of uric acid stone formation) should be detected by a 24 hour urinary urate estimation with the patient on a low purine diet. ${ }^{1}$

Very rarely will the doctor have to prescribe urate lowering drugs. Mild hyperuricaemia may safely be left untreated, but opinions differ about high concentrations-say, above $540 \mu \mathrm{mol} / 1$. This degree of sustained hyperuricaemia is rare without some readily apparent underlying cause, but many would hold that such people, particularly if hyperuricosuric, should be treated with allopurinol. The drug does, however, have side effects, and in recent reports of deaths from allopurinol toxicity the drug has been prescribed in many cases for trivial and inadequate reasons. ${ }^{1011}$

J T ScotT

Consultant Physician,

Department of Rheumatology,

Charing Cross Hospital,

London W6 8RF
1 Scott JT. Gout. In: Scott JT, ed. Copeman's textbook of the rheumatic diseases. 6th ed. Edinburgh: Churchill Livingstone, 1986:883-937.

Hall AP, Barry PE, Dawber T, McNamara PM. Epidemiology of gout and hyperuricemia. $A m \mathcal{J}$ Med 1967;42:27-37.

3 Fessel WJ. Hyperuricemia in health and disease. Semin Arthritis Rheum 1972;1:275-99.

4 Campion EW, Glynn RJ, DeLabry LO. Asymptomatic hyperuricemia: the risks and consequences in the Normative Aging Study. Am $\mathcal{F}$ Med (in press).

Kuzell WC, Schaffarzick RW, Naugler WE, et al. Some observations on 520 gouty patients. f Chronic Dis 1955;2:645-9.

6 Atsmon A, De Vries A, Frank M. Uric acid lithiasis. Amsterdam: Elsevier, 1963

7 Fessel WJ. Renal outcomes of gout and hyperuricemia. Am J Med 1979;67:74-82.

$8 \mathrm{Yü} \mathrm{T}$-F, Berger L. Impaired renal function in gout. $A m \mathcal{F}$ Med 1982;72:95-100.

Brand FN, McGee DL; Kannel WB, Stokes J III, Castelli WP. Hyperuricemia as a risk factor of coronary heart disease: the Framingham study. Am $\mathcal{F}$ Epidemiol 1985;121:11-8.

10 Singer JZ, Wallace SL. The allopurinol hypersensitivity syndrome: unnecessary morbidity and mortality. Arthrinis Rheum 1986;29:82-7.

11 Auböch J, Fritsch P. Asymptomatic hyperuricaemia and allopurinol toxic epidermal necrolysis. BrMed f 1986;290:1969-70.

\section{Atlantoaxial instability in Down's syndrome}

Patients with Down's syndrome may injure their cervical cords through atlantoaxial subluxation, and the sponsors of the special olympics in the United States have stopped them participating in high risk sporting activities until the presence of atlantoaxial instability has been excluded. ${ }^{1}$ Once it is excluded, however, they may participate without restriction. Similar advice has been given by the American Committee on Sports Medicine, ${ }^{2}$ and similar guidelines have been approved in Britain by the Royal Society for Mentally Handicapped Children and Adults (Mencap).

Advice from the Department of Health and Social Security, ${ }^{3}$ which has been endorsed by the British Orthopaedic Association (L Klernerman, personal communication), suggests that there is no justification for routine screening of all patients with Down's syndrome for atlantoaxial instability but only for those likely to engage in vigorous sporting activities, such as trampolining, diving, or violent contact sports. Those found to have normal radiographs of the cervical spine should not be restricted in their activities. Those found to have atlantoaxial instability but no abnormal neurological signs should be encouraged to continue with previous activities_-except more vigorous high risk sports. Alvarez, in contrast, believes that all patients with Down's syndrome should be screened both radiologically and neurologically at least annually. ${ }^{4}$

Atlantoaxial instability was recognised over 150 years ago, but its association with Down's syndrome became apparent only in the 1960s. Spitzer found that nine of 29 patients with Down's syndrome showed "forward displacement of the atlanto-occipital joint and an abnormally thin and small shape of the atlas vertebra." Many other skeletal abnormalities are to be found in Down's syndrome, including abnormalities of the odontoid process and laxity of the transverse ligament of the atlas. ${ }^{7-14}$ Since Spitzer's original observation several cases have been published of atlantoaxial subluxation in Down's syndrome associated with neurological problems, ${ }^{15-30}$ and sometimes spinal cord damage appears to have occurred either spontaneously or after minor trauma.

Tishner and Martel undertook a radiological examination of 18 patients with Down's syndrome and found an atlantoodontoid interval greater than $5 \mathrm{~mm}$ in four. ${ }^{31}$ Martel studied 70 patients with Down's syndrome "largely selected at random" (but mostly male) and found atlantoaxial instability in $14 . .^{32}$ Semine found an atlanto-odontoid interval greater than $4.5 \mathrm{~mm}$ in 10 of 85 children with Down's syndrome; 
after 12 months only one had developed neurological signs. ${ }^{33}$ Pueschel screened 236 patients with Down's syndrome radiologically and found the atlanto-odontoid interval equal to or greater than $5 \mathrm{~mm}$ in $17 \%$; in $2.6 \%$ of his patients (seven cases), only one of whom was over 18, atlantoaxial instability was associated with abnormal neurological signs $(18 \%$ of those in whom atlantoaxial instability had been shown radiologically). ${ }^{34}{ }^{35} \mathrm{Six}$ of his seven patients with neurological abnormalities had no history of trauma. The male to female ratio of those patients affected by atlantoaxial instability was $1: 2 \cdot 3$. Peuschel found that if the atlanto-odontoid interval was $4 \cdot 5-6 \cdot 0 \mathrm{~mm}$ the patients remained free of neurological signs, but if the distance exceeded 7.00 mm all patients had neurological signs. Peuschel believes that the intrinsic defect is one of connective tissue since atlantoaxial instability was correlated with hyperextensibility of other joints, such as fingers and elbows. ${ }^{33}{ }^{36}$

The prevalence of atlantoaxial instability in patients with Down's syndrome thus seems to be between $12 \%$ and $22 \%$, with a higher prevalence among girls and women. Atlantoaxial instability is associated with (and probably causes) damage to the cervical cord in some $2-3 \%$ of all patients with Down's syndrome who survive infancy. Most patients in whom cord damage has been recognised have undergone surgical procedures to stabilise the cervical spine, and the results have been generally good. ${ }^{21}{ }^{34}$ The fact that most cases of neurological damage seem to have occurred spontaneously or after trivial trauma is, however, worrying as avoiding strenuous sporting activity alone may thus not be enough to protect the cervical cord.

Atlantoaxial instability in Down's syndrome fulfils many of the criteria for introducing screening ${ }^{37}$ : the association of atlantoaxial instability with cord damage is common and often disastrous; the condition is treatable and easily diagnosed using acceptable and readily available methods; and there is a latent period before cord damage occurs. What is missing is an agreed policy on screening and treatment. The screening of all patients with Down's syndrome for atlantoaxial instability seems to be logical. Down's syndrome is common, and half of all the patients who survive infancy now live until $60 .{ }^{3840} \mathrm{It}$ is imperative to ensure their quality of life, but the workload and resource implications of so doing are enormous.

Richard A CollacotT

Lecturer in Psychiatry (Mental Handicap),

Clinical Sciences Building,

Leicester Royal Infirmary,

Leicester LE2 7LX

1 Cooke RE. Atlanto-axial instability in individuals with Down's syndrome. Ment Retard 1984;22:193-4.

Committee on Sports medicine. Atlanto-axial instability in Down's syndrome. Pediatrics 1984;74:152-4.

Acheson ED. Atlanto-axial instability in people with Down's syndrome. London: DHSS, 1986 (Circular letter $\mathrm{CMO}(86) 8$.

4 Alvarez N, Rubin L. Atlanto-axial instability in adults with Down's syndrome: a clinical and radiological survey. Appl Res Ment Retard 1986;7:67-78.

5 Bell C. The nervous system of the human body. London: Longman, 1830.

5 Bell C. The neroous system of the human body. London: Longman, 1830.
6 Spitzer R, Rabinowitch JY, Wybar KC. A study of the abnormalities of the skull, teeth and lenses Spitzer R, Rabinowitch JY, Wybar KC. A study of the
in mongolism. Can Med Assoc $\mathcal{F} 1961 ; 84: 567-72$.

in mongolism. Can Med Assoc $\mathcal{F} 1961 ; 84: 567-72$.
7 Benda CE. Mongolism and cretinism. New York: Grune and Stratton, 1946:201-9.

7 Benda CE. Mongolism and cretinism. New York: Grune and Stratton, 1946:201-9.

9 Hefke HW. Roentgenologic study of anomalies of the hands in one hundred cases of mongolism. Am f Dis Child 1940;60:1319-23.

10 Currarino G, Swanson GE. A developmental variant of ossification of the manubrium sterni in mongolism. Radiology 1964;82:916.

11 Horns JW, O'Loughlin BJ. Multiple manubrial ossification centres in mongolism. AfR 1965;93:395-8.

12 Mautner H. (1950). Abnormal findings on the spine in mongoloids. Am $\mathcal{J}$ Ment Defic 1950;55 $105-7$.

13 Rabinowitz JG, Moseley JE. The lateral lumbar spine in Down's syndrome: a new roentgen feature. Radiology 1964;83:74-9.

14 Diamond LS, Lynn D, Sigman B. Orthopaedic disorders in patients with Down's syndrome. Orthop Clin North Am 1981;12:57-71.
15 Aung MH. Atlanto-axial dislocation in Down's syndrome. Bulletin of the Los Angeles Neurological Sociery 1973;38:197-201.

16 Dzentis AJ. Spontaneous atlanto-axial dislocation in a mongoloid child with spinal cord compression. I Neurosurg 1966;25:458-60.

17 Kleinman PK. Case report. Skeletal Radiol 1983;10:192-5.

18 Grobovschek $M$, Strohecker J. Congenital atlanto-axial subluxation in Down's syndrome. Neuroradiology 1985;27:186-7.

19 Dawson EG, Smith L. Atlanto-axial subluxation in children due to vertebral anomalies. $\mathcal{f}$ Bone foint Surg (Am) 1979;61:582-7.

20 Sherk HH, Nicholson JT. Rotatory atlanto-axial dislocation associated with ossiculum terminale and mongolism. I Bone foint Surg (Am) 1969;51:957-64.

21 Hungerford GD, Akkaraju V, Rawe SE, Young GF. Atlanto-occipital and atlanto-axial dislocations with spinal cord compression in Down's syndrome. Br f Radiol 1981;54:785-61.

22 Andrews LG. Myelopathy due to atlanto-axial dislocation in a patient with Down's syndrome and rheumatoid arthritis. Dev Med Child Neurol 1981;23:356-60.

23 Whaley WJ, Gray WD. Atlanto-axial dislocation with Down's syndrome. Can Med Assoc $\mathcal{f}$ 1980;123:35-7.

24 Shield LK, Dickens DRV, Jensen F. Atlanto-axial dislocation with spinal cord compression in Down's syndrome. Aust Paediatr f 1981;17:1146.

25 Giblin PE, Micheli LJ. (1979). The management of atlanto-axial subluxation with neurological involvement in Down's syndrome. Clin Orthop 1979;140:66-71.

26 Herring JA. Cervical instability in Down's syndrome and juvenile rheumatoid arthritis. $\mathcal{F}$ Paediatr Orthop 1982;2:205-7.

27 Finerman GA, Sakai D, Weingarten S. Atlanto-axial dislocation with spinal cord compression in a mongoloid child. F Bone foint Surg (Am) 1976;58:408-9.

28 Hreidarsson S, Magram G, Singer H. Symptomatic atlanto-axial dislocation in Down's syndrome. Pediatrics 1981;69:568-71.

29 Martel W, Vyham R, Stimson CW. Subluxation of the atlas causing spinal cord compression in a case of Down's syndrome. Radiology 1969;93:839-40.

30 Wang A-M, Fischer EG, Ofori-Kwakye SK, Rumbaugh CL, Lewis ML. Posterior fossa ependymal cyst and atlanto-axial subluxation in a patient with Down's syndrome: CT findings. I Comput Assist Tomogr 1984;8:783-7.

31 Tishler J, Martel W. Dislocation of the atlas in mongolism. Radiology 1965;84:904-6.

31 Tishler J, Martel W. Dislocation of the atlas in mongolism. Radiology 1965;84:904-6.

33 Semine AA, Ertel AN, Goldberg MJ, Bull MJ. Cervical spine instability in children with Down's Semine AA, Ertel AN, Goldberg MJ, Bull MJ. Cervical
syndrome. J Bone foint Surg (Am) 1978;60:649-52.

34 Peuschel SM, Herndon JH, Gelch MM, Senft KE, Scola FH, Goldberg MJ. Symptomatic atlantoaxial subluxation in persons with Down's syndrome. $\mathcal{A}$ Pediat Orthop 1984;4:682-8.

35 Peuschel SM. Atlanto-axial subluxation in Down's syndrome. Lancet 1983;i:980.

36 Peuschel SM, Scola FH, Perry CD, Pezzullo JC. Atlanto-axial instability in children with Down's syndrome. Pediatr Radiol 1981;10:129-32.

37 Wilson JMG. Some principles of early diagnosis and detection. In: Teeling-Smith G, ed. Surveillance and early diagnosis in general practice. London: Office of Health Economics, 1966: 5-10.

38 Duport A, Vaeth $M$, Videbech $P$, et al. Mortality and life expectancy of Down's syndrome in Denmark. I Ment Defic Res 1986;36:111-20.

39 Fryers T. Survival in Down's syndrome. $\mathcal{J}$ Ment Defic Res 1986;30:101-10.

40 Oster J, Mikkelsen M, Nielsen A, et al. Mortality and life table in Down's syndrome. Acta Paediatr Scand 1975;64:322-6.

\section{Measles and the government}

Some time soon children in Britain will be offered a triple vaccine against measles, mumps, and rubella at the age of 15 months. An announcement has been expected for several months, and on 7 April Baroness Trumpington, Parliamentary Secretary for Health, in a curious choice of venue, told Princess Diana and others present at a lunch organised by the National Rubella Council that "we shall take every step to introduce this vaccine generally as soon as practicable." "

The $B M \mathcal{F}$ has for years been calling for a more effective campaign of measles vaccination, ${ }^{2}$ and we have also published evidence on the safety and efficacy of the measles/ mumps/rubella vaccine as used in Sweden and elsewhere. ${ }^{3}$ Introduction of the new triple vaccine could and should give community physicians, health educators, family doctors, health visitors, and others an opportunity to revitalise the measles campaign and raise the uptake above the present disappointing $60 \%$. The World Health Organisation's target -elimination of measles from Europe by 1995-depends on a $95 \%$ uptake of measles vaccination by 1990 , so there is not a lot of time. ${ }^{4}$

The lack of any date in the government's announcement is disappointing. It does, however, encourage us to urge the Department of Health to do the job properly this time round. Firstly, mumps and rubella should be made notifiable in order to provide background data. Secondly, once a launch 